\title{
Endocrine changes in sows weaned at two stages of lactation
}

\author{
S. Edwards* and G. R. Foxcroft \\ A.R.C. Research Group on Hormones and Farm Animal Reproduction, University of Nottingham, \\ Faculty of Agricultural Sciences, Sutton Bonington, Loughborough, Leics LE12 SRD, U.K.
}

\begin{abstract}
Summary. Plasma concentrations of LH, FSH, prolactin, oestradiol-17 $\beta$ and progesterone were determined in 18 multiparous sows at 4-h intervals for 15-18 days around weaning at 3 or 5 weeks post partum. Sampling at 10 -min intervals for $6 \mathrm{~h}$ occurred every 2 days throughout the same period. Shortening lactation significantly reduced the preovulatory LH surge and altered the pattern of FSH release. However, there was no significant effect on ovulation rate or interval from weaning to oestrus between groups. Weaning was consistently associated with a significant rise in basal LH concentrations whilst FSH secretion remained unaffected. Lactation length did not appear to affect the characteristics of episodic LH secretion before weaning, nor were any consistent changes in $\mathrm{LH}$ secretion apparent until the preovulatory rise in $\mathrm{LH}$. Plasma prolactin values declined rapidly at weaning and remained low thereafter. These results indicate that the 'trigger' controlling the return to cyclic ovarian activity after weaning in the pig is complex, but it is suggested that lactational anoestrus and anovulation result primarily from a lack of $\mathrm{LH}$ stimulation to the ovary.
\end{abstract}

\section{Introduction}

Lactation in the pig is normally characterized by a suppression of oestrus and ovulation. The mechanisms controlling this are unclear, but have been associated with the suckling stimulus (Lauderdale, Kirkpatrick, First, Hauser \& Casida, 1965; Peters, First \& Casida, 1969). It is possible, in certain circumstances, to terminate lactational anoestrus by temporary removal of the sow from her litter (Smith, 1961; Crighton, 1970).

The influence of lactation length on general reproductive performance after weaning has been extensively studied and most authors agree that decreasing lactation length adversely affects subsequent sow reproductive performance (e.g. Self \& Grummer, 1958; Moody \& Speer, 1971; Cole, Varley \& Hughes, 1975; Varley \& Cole, 1976a, b). Although there are a number of studies on the endocrine control of the porcine oestrous cycle (Niswender, Reichert \& Zimmerman, 1970; Henricks, Guthrie \& Handlin, 1972; Rayford, Brinkley, Young \& Reichert, 1974), the endocrine consequences of early weaning are unknown and an understanding of such interrelationships during lactation and after weaning could provide invaluable information with which to increase the breeding efficiency of the sow. This study therefore aimed to elucidate and clarify the relationships between LH, FSH, prolactin, oestradiol-17 $\beta$ and progesterone in sows during the late stages of lactation and for the first 14 days after weaning at 3 or 5 weeks post partum.

* Present address: The Agricultural Institute, Grange, Dunsany, Co. Meath, Ireland. 


\section{Materials and Methods}

Experimental procedures. The multiparous Landrace $\times$ (Landrace $\times$ Large White) or Landrace $\times$ Large White sows used were nursing litters of 4-10 piglets $(7 \cdot 8 \pm 0 \cdot 4)$ at the start of the experiment. All had normal reproductive histories, having reared at least 4 previous litters, and had been subjected to normal management during the existing lactation. Sows were weaned at 3 or 5 weeks post partum and were surgically provided with indwelling jugular cannulae after weaning (10 sows) or 3-5 days before weaning (8 sows) with weaning designated as Day 0 . Of the 10 sows cannulated after weaning, 6 were weaned after 5 weeks and 4 after 3 weeks of lactation. Of the 8 sows cannulated before weaning, 6 were weaned after 5 weeks and 2 after 3 weeks of lactation. Sows were studied over the 8-month period from June to February with 3-and 5-week weaned sows being represented at the times at which sampling occurred.

Blood samples were taken at 10-min intervals for periods of $6 \mathrm{~h}$ on Days -2 or $-1,0$ and 2 in sows cannulated before weaning and similarly every 2 days from Day 0 until Day 12 in the sows cannulated after weaning. In addition blood samples were withdrawn each day at 4-h intervals between $08: 00$ and 24:00 h from the day after cannulation until slaughter at Day 14. At slaughter the ovaries were checked macroscopically for evidence of ovulation and the number of corpora lutea (CL) was noted. Samples from the 4-h profiles were analysed for progesterone, oestradiol-17 $\mathrm{LH}, \mathrm{FSH}$, and, in selected instances, prolactin. Samples from the $6-\mathrm{h}$ 'window' profiles were assayed for $\mathrm{LH}$ alone.

A daily visual check was carried out for oestrus in the absence of boars but with sows allowed free movement within the animal crates in which sampling was carried out; sows which showed vulval reddening, mucous discharge and a positive back-pressure test were classified as being in oestrus.

Hormone assays. Plasma progesterone (Haresign, Foster, Haynes, Crighton \& Lamming, 1975), LH (Foxcroft, Pomerantz \& Nalbandov, 1975) and prolactin (van Landeghem \& van de Wiel, 1978 ) concentrations were measured by previously validated radioimmunoassays. Inter- and intraassay coefficients of variance (CV) were 11.8 and $3.8 \%$ and 9.8 and $14 \%$ for $\mathrm{LH}$ and progesterone respectively. All samples for prolactin were analysed in a single assay. The assay sensitivities were $0.8 \mathrm{ng}$ progesterone $/ \mathrm{ml}$ and $0.8 \mathrm{ng}$ prolactin $/ \mathrm{ml}$.

FSH concentrations were measured as described by Webb, Lamming, Haynes \& Foxcroft (1980) and Foxcroft, Elsaesser, Stickney, Back \& Haynes (1983) using ${ }^{125}$ I-labelled rat FSH and NIH-FSH-P2 porcine standard. The minimum detectable amount of FSH in these assays, defined as the inhibition curve value at twice the s.d. below the mean inhibition in the absence of unlabelled antigen, was $30 \mathrm{ng} / \mathrm{ml}$ using $100 \mu \mathrm{l}$ of sample. The inter- and intra-assay CVs were 14 and $4.0 \%$ respectively.

Oestradiol-17 $\beta$ was analysed by the method of Foxcroft et al. (1983) using duplicate determinations of 0.5 or $1.0 \mathrm{ml}$ plasma. Average recovery of oestradiol-17 $\beta$ was $95 \%$ and the interand intra-assay CVs were 8 and $10 \%$ respectively; the minimal detectable amount of oestradiol- $17 \beta$, defined as above, was $10 \mathrm{pg} / \mathrm{ml}$ using $1.0 \mathrm{ml}$ sample.

Statistical analysis. All differences between means were analysed by Student's $t$ test or analysis of variance as appropriate using a Genstat V (Mark 4.01) programme from the Rothamsted Experimental Station which accounted for inter-animal variation. For those assays in which some estimates were below the limit of assay sensitivity, the minimal detectable dose was used as the potency estimate for statistical analysis $(1.0 \mathrm{ng} / \mathrm{ml}$ for $\mathrm{LH}$ estimates; $10 \mathrm{pg} / \mathrm{ml}$ for oestradiol- $17 \beta$ estimates). Overall changes in hormone values based on 4-h estimates were therefore compared for periods during which concentrations were partly or consistently below assay sensitivity (but for which true absolute values could not be assigned) and periods when concentrations were consistently above assay sensitivity (for which true absolute values could be used for analysis).

With respect to the frequent $(10 \mathrm{~min})$ sampling for $\mathrm{LH}$, two patterns of secretion were apparent. One was represented by discrete episodes of $\mathrm{LH}$ release, as defined by an immediate rise from 
baseline to peak levels (within $10 \mathrm{~min}$ ) followed by an exponential decline during at least the 3 samples following this rise. When this episodic pattern was evident the frequency and amplitude of the episodes were determined. The second pattern of LH release involved smaller 'episodes' of LH, which did not meet the criteria above and hence were not analysed, or a more random but uniform change in overall baseline concentrations; in this case the overall mean LH value was used for analysis.

\section{Results}

\section{$L H$}

Samples every $4 \mathrm{~h}$. Of the 18 sows studied, 16 showed a preovulatory surge of LH within 7 days of weaning, as evidenced by continuously elevated LH levels over $\sim 20$ - $h$ as described by other authors; all these sows subsequently ovulated. These animals represented $11 / 12$ sows weaned after 5 weeks $(17 \cdot 3 \pm 1 \cdot 3$ (s.e.m.) CL) and $5 / 6$ sows weaned after 3 weeks of lactation $(15 \cdot 2 \pm 2 \cdot 6 \mathrm{CL})$. Of the 2 remaining sows, 1 weaned at 5 weeks post partum exhibited a preovulatory LH surge on Day 12 and the other, weaned at 3 weeks post partum, did not have an LH surge within 14 days of weaning and no follicular development was apparent at slaughter. The mean interval from weaning to peak LH surge levels was not significantly different between the two groups of sows (146.4 \pm $11.4 \mathrm{~h}$ for 3 -week weaners and $128 \cdot 3 \pm 18 \cdot 1 \mathrm{~h}$ for 5 -week weaners).

Weaning was consistently associated with a significant $(P<0.001)$ but transient rise in basal LH concentrations, as shown in Text-fig. 1, usually lasting for up to 2 days after which concentrations returned to lower values coincident with the increased secretion of oestrogen before oestrus; no significant difference in basal LH levels was apparent between groups. At oestrus, however, the mean peak LH concentrations for the 3- and 5-week weaned sows were $10.0 \pm 0.8$ and $16.6 \pm 1.9 \mathrm{ng} / \mathrm{ml}$ plasma respectively and were significantly different $(P<0.05)$, as were the total

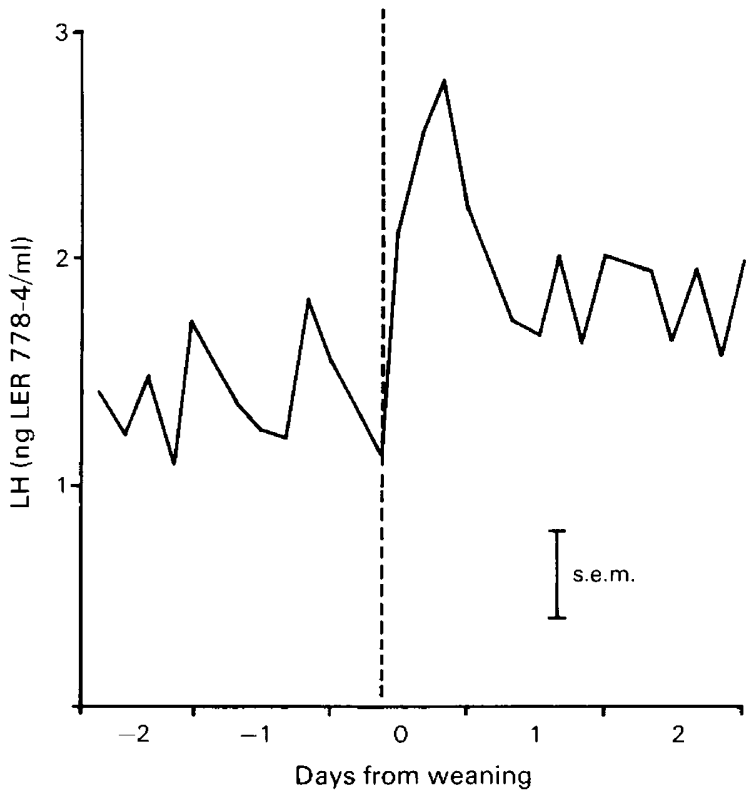

Text-fig. 1. Overall mean plasma LH concentrations for 3- and 5-week weaned sows normalized to $08: 00$ hours on the day of weaning (vertical broken line). The samples were taken every $4 \mathrm{~h}$ (see text). 
amounts of LH secreted during the preovulatory surge, as defined by arbitrary units of area under the curve ( 3 weeks, $368.2 \pm 38.9$ units; 5 weeks, $917.4 \pm 135.7$ units: $P<0.01$ ). The period after the preovulatory surge was once again characterized by low levels of LH secretion in both groups of sows (see Text-figs 2 and 3).

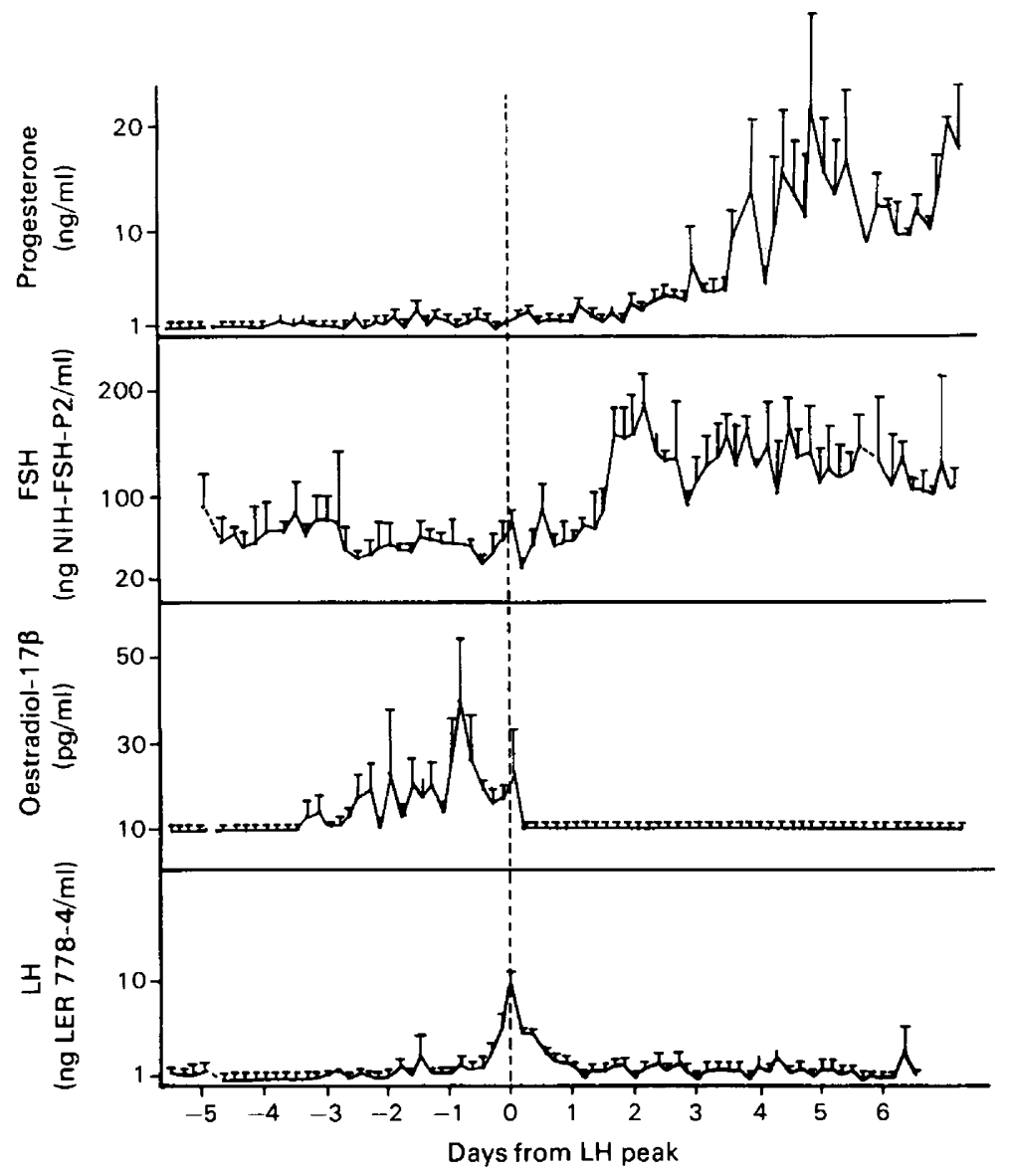

Text-fig. 2. Mean plasma concentrations of progesterone, oestradiol-17ß, FSH and LH for 3week weaned sows normalized to the first preovulatory LH surge after weaning.

Frequent sampling. The variable characteristics of episodic LH secretion as determined by the periods of frequent sampling in suckled and weaned sows are shown in Text-fig. 4. Before weaning in $5 / 8$ sows $\mathrm{LH}$ was secreted at a low basal level upon which were superimposed irregular but discrete episodic fluctuations with no consistent effect of the length of lactation on the pattern of episodic LH secretion observed (mean episodic frequency and amplitude $=1.5 \pm 0.5 \mathrm{pulses} / 6 \mathrm{~h}$ and $4.3 \pm 0.5 \mathrm{ng} / \mathrm{ml}$ ( 2 sows) and $3.3 \pm 0.7$ pulses $/ 6 \mathrm{~h}$ and $2.5 \pm 0.2 \mathrm{ng} / \mathrm{ml}$ ( 3 sows) for $3-$ and $5-$ week weaned sows respectively). The remaining 3 sows (5-weeks weaned) showed no episodic LH release pattern before weaning. After weaning an increase in basal LH concentration mirrored the overall increase revealed by the 4-h profiles (see Text-fig. 1). Although in some sows this appeared to be associated with increased episodic release, in others a more random, and, by definition, nonepisodic mode of secretion was present. The rising titre of oestradiol appeared to suppress episodic 


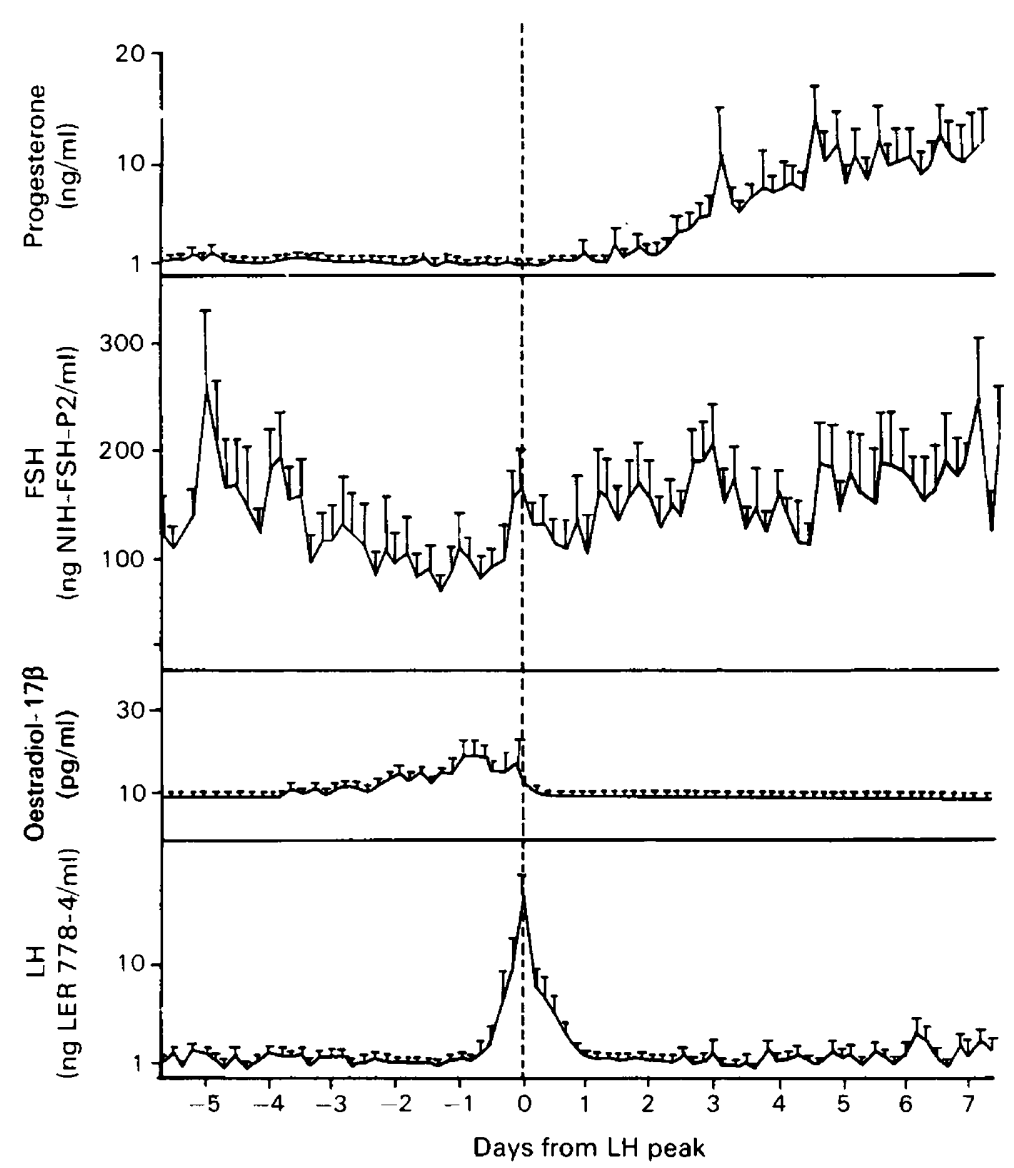

Text-fig. 3. Mean plasma concentrations of progesterone, oestradiol-17ß, FSH and LH for 5week weaned sows normalized to the first preovulatory LH surge after weaning.

LH secretion when it existed, whilst at the same time suppressing LH baseline concentrations to below the assay sensitivity. The characteristics of episodic LH secretion after the preovulatory surge (Days 10-12 after weaning) show that a rise in pulse amplitude $(6 \cdot 3 \pm 0.6 \mathrm{ng} / \mathrm{ml}$ ), associated with a decrease in pulse frequency $(2.0 \pm 0.4$ episodes $/ 6 \mathrm{~h})$, accompanied the increased secretion of progesterone during the luteal phase of the first oestrous cycle after weaning (Text-fig. 5).

\section{FSH}

Plasma FSH concentrations during lactation tended to be higher in the 5-week than in the 3week weaned sows although the variation between animals was large. In contrast to LH, basal FSH concentrations were not consistently stimulated by weaning $(P<0.05)$ (Text-fig. 6), but a rise in plasma FSH concentrations occurred in $5 / 8$ sows studied, usually beginning on the day of weaning and lasting for 2-3 days. FSH concentrations gradually declined coincident with the enhanced secretion of oestradiol before oestrus (see Text-figs 2 and 3).

At oestrus there was again a difference between the two groups of sows in the secretion of FSH. A distinct surge of FSH occurred coincidentally with the preovulatory surge of LH in 8/12 5-week weaned animals in contrast to $0 / 6$ sows weaned after 3-weeks of lactation. 


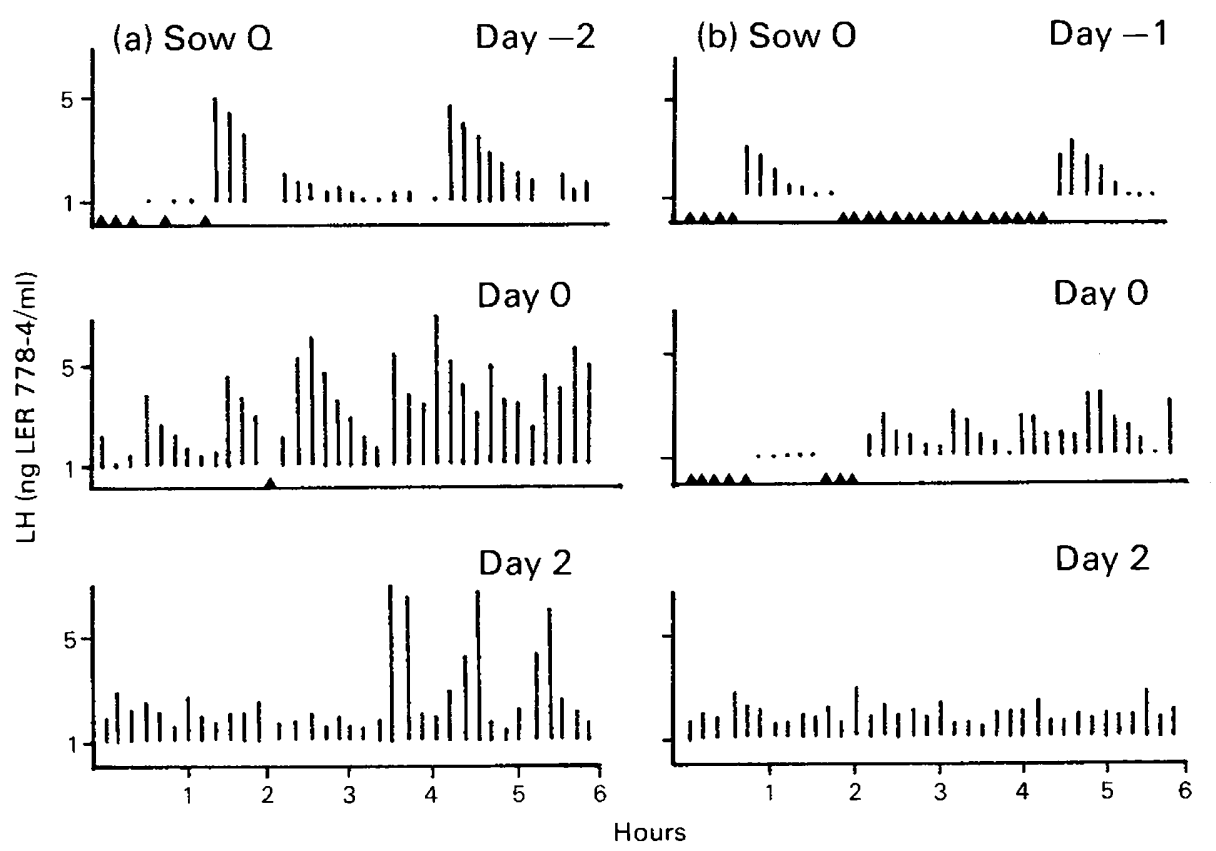

Text-fig. 4. Episodic LH profiles around weaning for 2 sows weaned after (a) 3 weeks and (b) 5 weeks of lactation. Weaning occurred on Day 0 and plasma progesterone concentrations were basal and plasma oestradiol-17 $\beta$ concentrations were $10 \mathrm{pg} / \mathrm{ml}$ at all times. Concentrations marked $\Delta$ below $1 \mathrm{ng} / \mathrm{ml}$ were below the sensitivity of the assay.
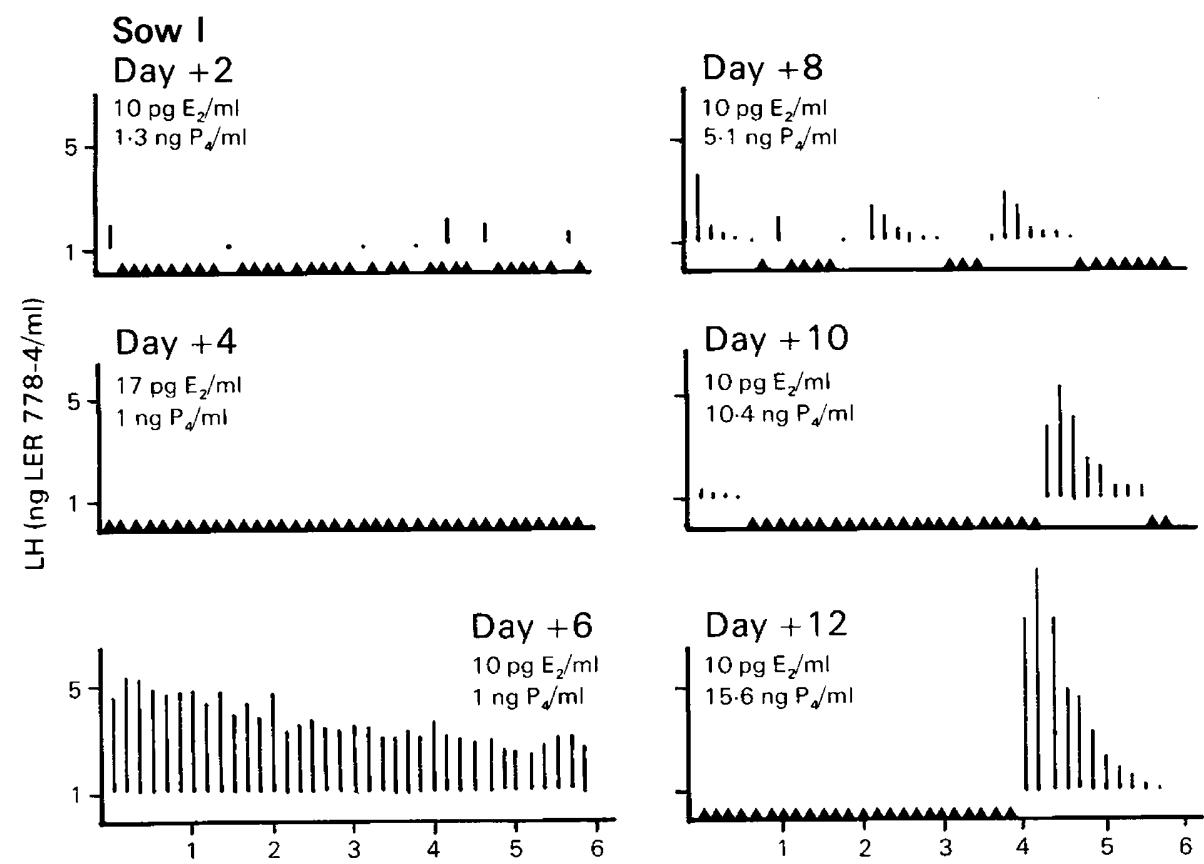

Text-fig. 5. Episodic LH secretion in a sow during the first 12 days after weaning at 5 weeks post partum. The preovulatory $\mathrm{LH}$ surge occurred on Days 5 to $6 . \mathrm{P}_{4}=$ progesterone; $\mathrm{E}_{2}=$ oestradiol-17 $\beta$. Concentrations marked $\Delta$ below $1 \mathrm{ng} / \mathrm{ml}$ were below the sensitivity for the particular assay. 


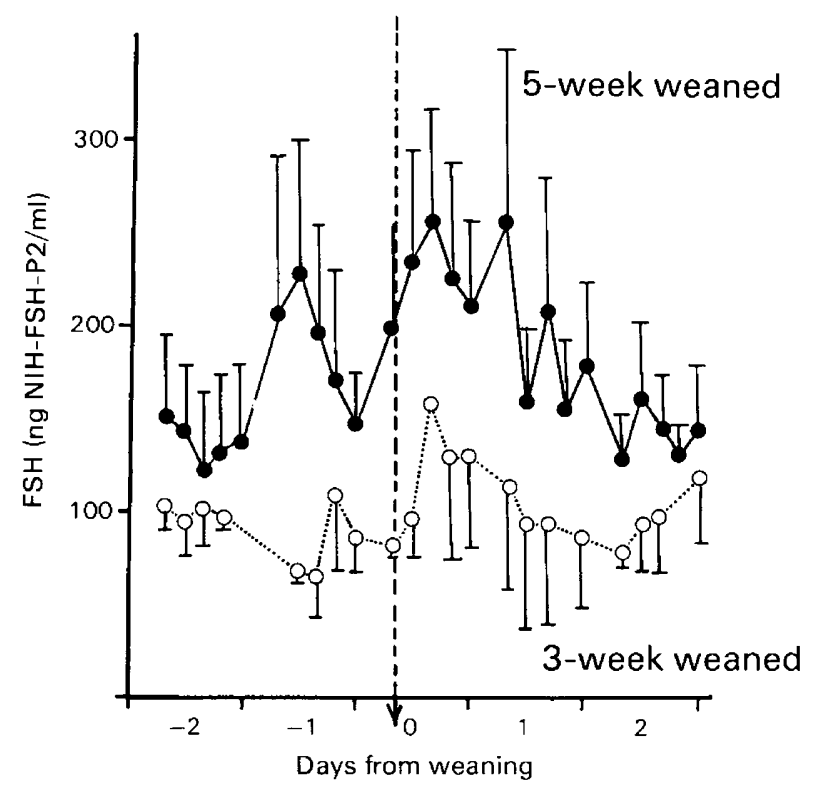

Text-fig. 6. Mean \pm s.e.m. plasma FSH concentrations for 3- and 5-week weaned sows normalized to $08: 00 \mathrm{~h}$ on the day of weaning (vertical broken line).

The period after the preovulatory gonadotrophin surge and before the onset of progesterone secretion, however, was characterized by a sustained 2-3-day period of FSH secretion in all sows, with no difference between the two groups of sows. Generally, but not invariably, FSH levels declined during the initial rise in plasma progesterone concentrations (see Text-figs 2 and 3).

\section{Oestradiol-17 $\beta$}

The concentrations of oestradiol- $17 \beta$ in plasma rose to measurable levels some $2-6$ days after weaning in 14 of the 18 sows studied; this rise preceded the induction of a preovulatory LH surge by 2-4 days and plasma oestradiol concentrations generally declined coincidentally with the preovulatory LH surge and remained low thereafter (see Text-figs $2 \& 3$ ). Although the peak levels of oestradiol before oestrus varied between 13 and $75 \mathrm{pg} / \mathrm{ml}$ plasma (overall mean $31 \pm 4 \mathrm{pg} / \mathrm{ml}$ ), there was no apparent correlation between the length of lactation and the peak levels of oestradiol observed ( $41 \pm 10 \mathrm{pg} / \mathrm{ml}$ at 3 weeks; $27 \pm 3 \mathrm{pg} / \mathrm{ml}$ at 5 weeks). Of the 4 remaining sows, 1 showed a rise in plasma oestradiol-17 $\beta$ on Days 9-12 (and a subsequent LH surge on Day 12), 2 sows had elevated levels of oestradiol during the later stages of lactation and LH surges on Days 2 and 3 after weaning, respectively, and the 4th sow did not return to oestrus or show a rise in plasma oestradiol before slaughter at Day 14.

\section{Progesterone}

Mean plasma progesterone concentrations before and after ovulation in both groups of sows are shown in Text-figs $2 \& 3$. Low but detectable amounts of progesterone $(2-4 \mathrm{ng} / \mathrm{ml}$ for periods of $4-$ $48 \mathrm{~h}$ ) were observed in $11 / 18$ sows before the LH surge and concentrations then rose markedly 1-3 days later. 


\section{Prolactin}

Plasma concentrations of prolactin were high during lactation and declined rapidly to reach basal values $(<1-2 \mathrm{ng} / \mathrm{ml})$ within a very few hours of weaning as shown in Table 1 . There was no significant difference between the groups in the prolactin concentrations during lactation or in the rate of decline in prolactin after weaning. Although prolactin values were generally low from weaning to slaughter, there was some evidence for a rise in prolactin concentrations at oestrus in $2 / 5$ sows. Prolactin concentrations in the sow that did not return to oestrus or ovulate before slaughter were not different from those of the remaining sows.

Table 1. Plasma prolactin concentrations around weaning (time 0 ) of sows at 3 and 5 weeks post partum

\begin{tabular}{cccccc}
\hline \multirow{2}{*}{$\begin{array}{c}\text { Lactation length } \\
\text { (weeks) }\end{array}$} & No. of sows & $-44 \mathrm{~h}$ & $-8 \mathrm{~h}$ & $+4 \mathrm{~h}$ & $+16 \mathrm{~h}$ \\
\cline { 3 - 6 } & 3 & $16 \cdot 6 \pm 1 \cdot 0$ & $19 \cdot 6 \pm 6 \cdot 3$ & $5 \cdot 0 \pm 1 \cdot 6$ & $2 \cdot 4 \pm 0 \cdot 3$ \\
\hline 5 & 2 & $28 \cdot 4 \pm 6 \cdot 4$ & $18 \cdot 4 \pm 4 \cdot 6$ & $3 \cdot 4 \pm 0 \cdot 2$ & $2 \cdot 1 \pm 0 \cdot 1$ \\
\hline 3 & &
\end{tabular}

\section{Discussion}

Although the limited number of sows studied did not, as expected, reveal any significant differences in overall fertility related to the length of lactation, the trend for a longer interval from weaning to oestrus and a reduced ovulation rate in the early weaned sows are consistent with previous more extensive data from this herd (Cole et al., 1975; Varley \& Cole, 1976b) and from other studies (see 'Introduction'). In view of this established trend it was our intention to utilize the extensive endocrine data obtained in the present study to substantiate earlier observations on the patterns of hormone secretion before and after weaning and to determine a possible endocrine basis for reduced fertility in early weaned animals.

The suppressed levels of plasma LH seen during lactation support the hypothesis that suckling and lactation may inhibit follicular growth and ovulation by limiting LH secretion (Melampy, Henricks, Anderson, Chen \& Schultz, 1966; Crighton \& Lamming, 1969; Parvizi, Elsaesser, Smidt \& Ellendorff, 1976; Stevenson \& Britt, 1980; Stevenson, Cox \& Britt, 1981). The mechanisms by which suckling and lactation suppress LH release are unclear but may involve a direct neural suppression of GnRH synthesis and release, as hypothalamic stores of GnRH are lower at weaning than at any time during the weaning to oestrus interval in the pig (Cox \& Britt, 1981). Although the infrequency of episodic $\mathrm{LH}$ release during lactation in the present study and the rise in basal $\mathrm{LH}$ secretion at weaning are consistent with this hypothesis, the use of frequent sampling has demonstrated that lactation does not effect an absolute block to LH secretion.

In contrast, plasma FSH concentrations did not appear to be significantly depressed in the present study during lactation when compared to FSH levels after weaning and during the oestrous cycle of the sow (Foxcroft \& van de Wiel, 1982). However, our data, in agreement with those of Stevenson et al. (1981), indicate that plasma FSH tends to increase as lactation progresses; this may have implications for the degree of follicular stimulation occurring before weaning and hence the ovarian response to any $\mathrm{LH} / \mathrm{FSH}$ rise associated with piglet removal. Although marked follicular development did not normally occur before weaning, as judged by the lack of detectable oestradiol secretion in 16/18 sows during lactation, in two 5-week weaned sows oestradiol levels were elevated to normal pre-oestrous levels during the later stages of lactation ( 31 and 33 days respectively). Sustained follicular development and steroidogenesis may therefore occur with episodic LH release and rising plasma FSH levels as lactation proceeds. 
The absence of oestrous behaviour and ovulation even in animals in which oestrogen secretion is observed before weaning may be related to the fact that even very high concentrations of exogenous oestrogen in the suckling sow will induce only a limited LH response at Day 35 of lactation, indicating that a blockade of the positive oestrogen feedback mechanism may be one cause of lactational anovulation (Elsaesser \& Parvizi, 1980).

Raised titres of prolactin in the plasma of lactating sows have been reported previously and such elevations appear to be maintained primarily by the suckling stimulus, because a rapid decline was observed after weaning (van Landeghem \& van de Wiel, 1978; Bevers, Willemse \& Kruip, 1978; Mulloy \& Malven, 1979). However, prolactin concentrations also decreased gradually as lactation progressed. A similar pattern of prolactin secretion was apparent in the limited number of sows studied in this experiment and the large between-animal variation reported previously may explain the apparent similarity in prolactin levels at 3 and 5 weeks of lactation.

The changes in progesterone and oestrogens that accompany weaning have been described previously (see Ash \& Heap, 1975; Baldwin \& Stabenfeldt, 1975). The data from this study are essentially similar and indicate that ovarian steroids play no role in the control of lactational anoestrus in the sow.

Previous studies of the changes in $\mathrm{LH}$ concentration indicated that the secretion of this hormone is unaffected by weaning (Aherne, Christopherson, Thompson \& Hardin, 1976; Parvizi et al., 1976; Stevenson \& Britt, 1980). However Crighton \& Lamming (1969) postulated that weaning functionally re-establishes $\mathrm{LH}$ secretion. The more frequent sampling regimens used in the present study have substantiated this latter hypothesis by showing that a significant rise in LH secretion consistently accompanies weaning. If it is accepted that a major factor controlling the lack of sustained follicular development during lactation is the inadequate secretion of LH (Stevenson \& Britt, 1980) then the weaning-associated rise in LH secretion, and particularly LH baseline, may be a major factor responsible for re-initiating sustained follicular growth. Similar increases in basal LH secretion are thought to be responsible for the initiation and continuance of the increased follicular growth before the return to oestrus in post-partum cattle (Lamming, 1978) and anoestrous sheep at the onset of the breeding season (Legan \& Karsch, 1980). Although the increase in LH baseline in cattle was associated with an increase in episodic LH activity (Peters, Lamming \& Fisher, 1981), our results suggest that a similar relationship does not exist in the pig. Continuous frequent sampling at the time of weaning might reveal a more direct relationship between episodic LH secretion and the increase in LH baseline.

FSH concentrations in the plasma of the 3-and 5-week weaned sows did not show a consistent rise at weaning and it may be deduced that a shift in basal FSH concentrations is not a prerequisite for the stimulation of follicular growth. Although FSH is obligatory for continued follicular development, its role after weaning may be more facilitatory to allow the increased LH levels to exert their stimulatory effect.

The post-weaning oestrus is the single most important event in re-breeding the sow post partum. Although circulating concentrations of oestrogens, progesterone, LH, FSH and prolactin at this time have all been reported previously (Ash \& Heap, 1975; Parvizi et al., 1976; Aherne et al., 1976; van Landeghem \& van de Wiel, 1978), concurrent analyses of these hormones at the post-weaning oestrus have not previously been available. The present study broadly supports the view that the endocrine changes occurring at the post-weaning oestrus are similar to those at oestrus in the cyclic sow (van de Wiel, Erkens, Koops, Vos \& van Landeghem, 1981). However, the absolute amount of LH released during the preovulatory surge after 3 weeks of lactation is significantly reduced in comparison to surge LH release in 5-week weaned or cyclic sows at oestrus. The physiological basis for this difference is unknown but could involve reduced pituitary sensitivity to endogenous GnRH at 3 weeks post partum (Bevers, Willemse, Kruip \& van de Wiel, 1981) and/or an actual decrease in endogenous GnRH release by the hypothalamus.

Furthermore, the surge release of FSH after shorter lactations is also disrupted when compared to either 5-week weaned or cyclic sows at oestrus (see van de Wiel et al., 1981). Since only 50-60\% of 
cyclic sows show a synchronous LH/FSH surge it may be argued that such responses are not essential for normal ovulation and/or continued cyclic activity, and so the lack of a preovulatory FSH surge in the sows after 3 weeks of lactation may be of little physiological importance. However, such data, when viewed in conjunction with the suppressed preovulatory LH secretion after shortened lactations, suggest that the early weaned sow suffers from a general lack of gonadotrophic activity at this crucial time before ovulation, although, as in this study, no significant depression in overall fertility may be present. Nevertheless, these observations provide the first endocrine evidence to suggest why reproductive performance in the sow is frequently affected by unduly shortening lactation.

A variable period of enhanced oestrogen secretion preceded the induction of the preovulatory LH surge but was not dissimilar to published data for the weaned sow (Ash \& Heap, 1975). The decline in plasma oestrogen concentrations coincident with the LH surge is consistent with the reported ability of LH to terminate oestrogen secretion in other species and with observations from cyclic sows at oestrus (van de Wiel et al., 1981; Foxcroft \& van de Wiel, 1982). Overall, the absolute levels of oestradiol before the LH surge appeared to be lower in the weaned sow than in the cyclic gilt and, together with a lack of progesterone priming, may be responsible for the increased number of sows which fail to show oestrus for $>20$ days after weaning in some herds.

Despite significant differences in the preovulatory gonadotrophin profiles between the 3- and 5week weaned sows, there was no significant difference in ovulation rate in this study and the pattern of progesterone secretion suggests that corpus luteum formation was normal.

Elevated concentrations of prolactin have been associated with anovulatory disorders in other species (Rolland, Lequin, Schellekens \& de Jong, 1975) but the continued secretion of prolactin after weaning does not appear to be responsible for the delayed return to oestrus seen in some sows in this and other studies (van de Wiel, van Landeghem, Willemse \& Bevers, 1979).

In conclusion, therefore, it appears that the length of lactation has a profound effect on several aspects of the hormonal response to weaning, and may provide a satisfactory physiological explanation for a tendency towards reduced fertility in early weaned sows. In particular, the characteristics of $\mathrm{LH}$ secretion are considered to be particularly important in re-establishing follicular development and further detailed studies of gonadotrophin secretion after weaning are essential.

In addition to the post-weaning differences in hormone secretion, in at least some 5-week weaned sows, there was evidence for substantial follicular development and even steroidogenesis during lactation and this was associated both with active, albeit suppressed, episodic LH activity and high levels of FSH release. As this enhanced endocrine activity at the hypothalamic, pituitary and ovarian levels during lactation was associated with an early return to oestrus, the endocrine events in lactation also merit further detailed study and may provide a practical basis for 'priming' sows before weaning to enhance their subsequent reproductive performance.

We thank Dr G. D. Niswender and Professor W. R. Butt and NIH, Bethesda, Maryland, for gifts of antiserum and purified hormone preparations; Mr M. Stainer and Mrs K. Stainer for assistance; and Dr D. F. M. van de Wiel, IVO, Schoonoord, Zeist, Netherlands, for the prolactin assays. This work was completed under research grants provided by the Meat and Livestock Commission to whom one of us (S.E.) is indebted for financial support.

\section{References}

Aherne, F.X., Christopherson, R.J., Thompson, J.R. \& Hardin, R.T. (1976) Factors affecting the onset of puberty, post-weaning oestrus and blood hormone levels in Lacombe gilts. Can. J. Anim. Sci. 56, 681692.
Ash, R.W. \& Heap, R.B. (1975) Oestrogen, progesterone and corticosteroid concentrations in peripheral plasma of sows during pregnancy, parturition, lactation and after weaning. J. Endocr. 64, 141-154.

Baldwin, D.M. \& Stabenfeldt, G.H. (1975) Endocrine 
changes in the pig during late pregnancy, parturition and lactation. Biol. Reprod. 12, 508-515.

Bevers, M.M., Willemse, A.H. \& Kruip, Th.A.M. (1978) Plasma prolactin levels in the sow during lactation and the post-weaning period as measured by radioimmunoassay. Biol. Reprod. 19, 628-634.

Bevers, M.M., Willemse, A.H., Kruip, Th.A.M. \& van de Wiel, D.F.M. (1981) Prolactin levels and the LH response to synthetic LHRH in the lactating sow. Anim. Reprod. Sci. 4, 155-163.

Cole, D.J.A., Varley, M.A. \& Hughes, P.E. (1975) Studies in sow reproduction. 2. The effect of lactation length on the subsequent reproductive performance of the sow. Anim. Prod. 20, 401-406.

Cox, N.M. \& Britt, J.H. (1981) Relationship between endogenous GnRH and post-weaning endocrine events in sows. J. Anim. Sci. 53, Suppl. 1, 30-31, Abstr. 73 .

Crighton, D.B. (1970) Induction of pregnancy during lactation in the sow. J. Reprod. Fert. 22, 223-231.

Crighton, D.B. \& Lamming, G.E. (1969) The lactational anoestrus of the sow; the status of the anterior pituitary-ovarian system during lactation and after weaning. J. Endocr. 43, 507-519.

Elsaesser, F. \& Parvizi, N. (1980) Partial recovery of the stimulatory oestrogen feedback action on $\mathrm{LH}$ release during late lactation in the pig. J. Reprod. Fert. 59, $63-67$.

Foxcroft, G.R. \& van de Wiel, D.F.M. (1982) Endocrine control of the oestrous cycle. In Control of Pig Reproduction, Ch. 8, pp. 161-177. Eds D. J. A. Cole \& G. R. Foxcroft. Butterworths, London.

Foxcroft, G.R., Pomerantz, D.K. \& Nalbandov, A.V. (1975) Effects of estradiol-17 $\beta$ on LHRH/FSHRH induced and spontaneous $\mathrm{LH}$ release in pre-pubertal female pigs. Endocrinology 96, 551-557.

Foxcroft, G.R., Elsaesser, F., Stickney, K., Back, H.L. \& Haynes, N.B. (1983) Ovarian oestrogen-dependent maturation of the $\mathrm{LH} / \mathrm{FSH}$ surge mechanism during prepubertal development in the gilt. $J$. Endocr.

Haresign, W., Foster, J.P., Haynes, N.B., Crighton, D.B. \& Lamming, G.E. (1975) Progesterone levels following treatment of seasonally anoestrous ewes with synthetic LH-releasing hormone. J. Reprod. Fert. 43, 269-279

Henricks, D.M., Guthrie, H.D. \& Handlin, D.L. (1972) Plasma estrogen, progesterone and $\mathrm{LH}$ levels during the estrous cycle in pigs. Biol. Reprod. 6, 210-218.

Lamming, G.E. (1978) Reproduction during lactation. In Control of Ovulation, pp. 335-353. Eds D. B. Crighton, N. B. Haynes, G. R. Foxcroft \& G. E. Lamming. Butterworths, London.

Lauderdale, J.W., Kirkpatrick, R.L., First, N.L., Hauser, E.R. \& Casida, L.E. (1965) Ovarian and pituitary gland changes in peri-parturient sows. J. Anim. Sci. 24. $1100-1103$.

Legan, S.J. \& Karsch, F.J. (1980) Photoperiodic control of seasonal breeding in ewes: modulation of the negative feedback action of estradiol. Biol. Reprod. 23, 1061-1068.

Melampy, R.M., Henricks, D.M., Anderson, L.L., Chen, C.L. \& Schultz, J.R. (1966) Pituitary follicle-stimulating hormone and luteinizing hormone concentrations in pregnant and lactating pigs. Endocrinology $\mathbf{7 8}$, $801-804$.
Moody, N.W. \& Speer, V.C. (1971) Factors affecting sow farrowing interval. J. Anim. Sci. 32, 510-514.

Mulloy, A.L. \& Malven, P.V. (1979) Relationships between concentrations of porcine prolactin in blood serum and milk of lactating sows. J. Anim. Sci. 48, 876-881.

Niswender, G.D., Reichert, L.E. \& Zimmerman, D.R. (1970) RIA of serum levels of LH throughout the estrous cycle in pigs. Endocrinology 87, 576-580.

Parvizi, N., Elsaesser, F., Smidt, D. \& Ellendorff, F. (1976) Plasma LH and progesterone in the adult female pig during the oestrous cycle, late pregnancy and lactation, and after ovariectomy and pentobarbitone treatment. J. Endocr. 69, 193-203.

Peters, A.R., Lamming, G.E. \& Fisher, M.W. (1981) A comparison of plasma $\mathrm{LH}$ concentrations in milked and suckling post-partum cows. J. Reprod. Fert. 62, 567-573.

Peters, J.B., First, N.L. \& Casida, L.E. (1969) Effects of pig removal and oxytocin injections on ovarian and pituitary changes in mammillectomized, post-partum sows. J. Anim. Sci. 38, 537-541.

Rayford, P.L., Brinkley, H.J., Young, E.P. \& Reichert, L.E. (1974) Radioimmunoassay of porcine FSH. $J$. Anim. Sci. 39, 348-354.

Rolland, R., Lequin, R.M., Schellekens, L.A. \& de Jong, F.H. (1975) The role of prolactin in the restoration of ovarian function during the early post-partum period in the human female. I. A study during physiological lactation. Clin. Endocr. 4, 15-25.

Self, H.L. \& Grummer, R.H. (1958) The rate and economy of pig gains and the reproductive behavior in sows when litters are weaned at 10 days, 21 days or 56 days of age. J. Anim. Sci. 17, 862-868.

Smith, D.M. (1961) Effects of daily separation of sows from their litters upon milk yield, creep intake and energetic efficiency. N.Z. Jl agric. Res. 4, 232-245.

Stevenson, J.S. \& Britt, J.H. (1980) Luteinizing hormone, total oestrogens and progesterone secretion during lactation and after weaning in sows. Theriogenology 14, 453-462.

Stevenson, J.S., Cox, N.M. \& Britt, J.H. (1981) Role of the ovary in controlling LH, FSH and prolactin secretion during and after lactation in pigs. Biol. Reprod. 24, 341-353.

van Landeghem, A.A.J. \& van de Wiel, D.F.M. (1978) Radioimmunoassay for porcine prolactin: plasma levels during lactation, suckling and weaning and after TRH administration. Acta endocr., Copenh. 88, 653-667.

van de Wiel, D.F.M., van Landeghem, A.A.J., Willemse, A.H. \& Bevers, M.M. (1979) Endocrine control of ovarian function after weaning in the domestic sow. J. Endocr. 80, 69P, Abstr.

van de Wiel, D.F.M., Erkens, J., Koops, W., Vos, E. \& van Landeghem, A.A.J. (1981) Periestrous and midluteal time courses of circulating $\mathrm{LH}, \mathrm{FSH}$, prolactin, estradiol-17 $\beta$ and progesterone in the domestic pig. Biol. Reprod. 24, 221-224.

Varley, M.A. \& Cole, D.J.A. (1976a) Studies in sow reproduction. 4. The effect of level of feeding in lactation and during the interval from weaning to remating on the subsequent reproductive performance of the early weaned sow. Anim. Prod. 22, 7178.

Downloaded from Bioscientifica.com at 04/25/2023 11:43:16PM 
Varky, M.A. Cole, D.J.A. (1976b) Studies in sow reproduction. 5 . The effect of lactation length of the sow on the subsequent embryonic development. Anim. Prod. 22, 79-85.
Webb, R., Lamming, G.E., Haynes, N.B. \& Foxcroft, G.R. (1980) Plasma progesterone and gonadotrophin concentrations and ovarian activity in post-partum dairy cows. J. Reprod. Fert. 59, 133-143.

Received 2 June 1982 